\title{
Requirement for Tyrosine Phosphatase during Serotonergic Neuromodulation by Protein Kinase C
}

\author{
Stefano Catarsi and Pierre Drapeau \\ Centre for Research in Neuroscience, McGill University, and Montreal General Hospital Research Institute, Montreal, \\ Quebec, Canada H3G 1A4
}

\begin{abstract}
Tyrosine kinases and phosphatases are abundant in the nervous system, where they signal cellular differentiation, mediate the responses to growth factors, and direct neurite outgrowth during development. Tyrosine phosphorylation can also alter ion channel activity, but its physiological significance remains unclear. In an identified leech mechanosensory neuron, the ubiquitous neuromodulator serotonin increases the activity of a cation channel by activating protein kinase $C(P K C)$, resulting in membrane depolarization and modulation of the receptive field
\end{abstract}

properties. We observed that the effects on isolated neurons and channels were blocked by inhibiting tyrosine phosphatases. Serotonergic stimulation of PKC thus activates a tyrosine phosphatase activity associated with the channels, which reverses their constitutive inhibition by tyrosine phosphorylation, representing a novel form of neuromodulation.

Key words: single channel; serotonin; protein kinase C; tyrosine phosphorylation; identified neuron; leech
Regulation of ion channel activity by protein phosphorylation is a common mechanism of neuromodulation of transmitter-activated and voltage-gated ion channels (Kaczmarek and Levitan, 1987). The best characterized actions are those of the serine/threonine kinases activated by calcium or cyclic nucleotides, whose transient effects are terminated by dephosphorylation by protein phosphatases. More recently, tyrosine phosphorylation has been observed for various ligand-gated channels (Hopfield et al., 1988; Wang and Salter, 1994; Moss et al., 1995; Valenzuela et al., 1995) and voltagegated channels (Huang et al., 1993; Wilson and Kaczmarek, 1993; Lev et al., 1995; Holmes et al., 1996a,b; Jonas et al., 1996) and can alter channel activity and synaptic transmission (Llinas et al., 1997), but the physiological significance of this process is unproven. To examine the physiological role of tyrosine phosphorylation in modulating ion channels, we have been characterizing the properties of channels in identified neurons that are modulated by serotonin [5-hydroxytryptamine (5-HT)].

5 -HT is a modulator of neurons in a wide variety of species (Peroutka, 1993; Martin and Humphrey, 1994). We have shown that 5-HT modulates the receptive field properties of identified mechanosensory neurons of the leech (Mar and Drapeau, 1996). When these cells are isolated in culture, 5-HT retains its neuromodulatory effect, permitting a detailed analysis of the signal transduction pathway. In pressure-sensitive $(\mathrm{P})$ neurons, 5-HT binding to a $5-\mathrm{HT}_{2}$ receptor activates protein kinase $\mathrm{C}$ (PKC) (Sanchez-Armass et al., 1991), as in mammalian neurons (Peroutka, 1993; Martin and Humphrey, 1994), which then increases the activity of a cation channel (Drapeau, 1990; Catarsi and Drapeau, 1992, 1993). The channels are also activated when

Received March 7, 1997; revised May 6, 1997; accepted May 20, 1997.

This work was supported by a Medical Research Council (MRC) of Canada Fellowship to S.C. and by a Fonds de la Recherche en Santé du Québec Senior Research Scholarship and Medical Research Council grant to P.D. We thank P. V. Nguyen for his critical reading of this manuscript.

Correspondence should be addressed to Dr. Pierre Drapeau, Department of Neurology, Montreal General Hospital, 1650 Cedar Avenue, Montreal, Quebec, Canada H3G 1 A4.

Copyright (C) 1997 Society for Neuroscience $0270-6474 / 97 / 175792-06 \$ 05.00 / 0$ tyrosine phosphorylation is reversed by exposing intact $\mathrm{P}$ cells to inhibitors of tyrosine kinases or by treating isolated membrane patches with a catalytically active tyrosine phosphatase (Aniksztejn et al., 1997).

These observations suggest a constitutive suppression of channel activity by tyrosine phosphorylation. We tested for an interaction between PKC and tyrosine dephosphorylation during serotonergic modulation by treating cultured $\mathrm{P}$ cells or isolated membrane patches with vanadate, an inhibitor of tyrosine phosphatases (Swarup et al., 1982), before activating the channels with 5-HT, phorbol myristate acetate (PMA) (a membrane-permeant activator of PKC), or directly with PKC. In all cases the effects of the modulators were blocked, indicating that reversal of constitutive tyrosine phosphorylation underlies neuromodulation of the cation channels.

\section{MATERIALS AND METHODS}

$\mathrm{P}$ cells were isolated from Hirudo medicinalis and cultured as described previously (Dietzel et al., 1986). Because 5-HT activates both chloride and cation conductances in the P cell (Sanchez-Armass et al., 1991), the latter was isolated during intracellular recordings by blocking potassium channels with $10 \mathrm{~mm}$ diaminopyridine and by replacing external chloride with sulfate in the recording solution (Catarsi et al., 1995), which contained $130 \mathrm{~mm} \mathrm{Na} \mathrm{SO}_{4}, 4 \mathrm{~mm} \mathrm{~K} \mathrm{SO}_{4}, 5 \mathrm{~mm} \mathrm{MgSO}_{4}, 10 \mathrm{~mm} \mathrm{3,4-}$ diaminopyridine, $10 \mathrm{~mm}$ glucose, and $10 \mathrm{~mm}$ HEPES, $\mathrm{pH}$ 7.4, adjusted to $330 \mathrm{mOsm}$. In some experiments, chloride was replaced with gluconate, which gave similar responses to 5-HT and enhanced cell survival. Intracellular microelectrodes were filled with $4 \mathrm{~m}$ potassium acetate and had resistances of 40-50 M $\Omega$. 5-HT was applied by pressure ejection (15 psi) from a pipette with a tip opening of $5 \mu \mathrm{m}$. Sodium pervanadate was prepared freshly by mixing 1 part $500 \mathrm{mM} \mathrm{H}_{2} \mathrm{O}_{2}$ with 50 parts $10 \mathrm{~mm}$ sodium orthovanadate dissolved in saline; the solution was incubated for $15 \mathrm{~min}$ at room temperature to reduce $\mathrm{H}_{2} \mathrm{O}_{2}$ (Wallace, 1995). The mixture was then added at a final concentration of $100 \mu \mathrm{M} 1 \mathrm{hr}$ before the recordings were started.

Cell-attached recordings of cation channels were obtained as described previously (Drapeau, 1990; Catarsi and Drapeau, 1993). Briefly, cellattached patches were formed using 5-10 $\mathrm{M} \Omega$ electrodes filled with the same solution used to bathe the cells: $155 \mathrm{~mm} \mathrm{NaCl}, 5 \mathrm{mM} \mathrm{KCl}, 1 \mathrm{~mm}$ $\mathrm{MgCl}_{2}, 1 \mathrm{mM} \mathrm{CaCl}, 10 \mathrm{~mm}$ glucose, and $10 \mathrm{~mm}$ HEPES, pH 7.4, adjusted to $330 \mathrm{mOsm}$. PMA or genistein (LC Services Corp.) were diluted 2000- or 1000-fold, respectively, from a stock solution made in 


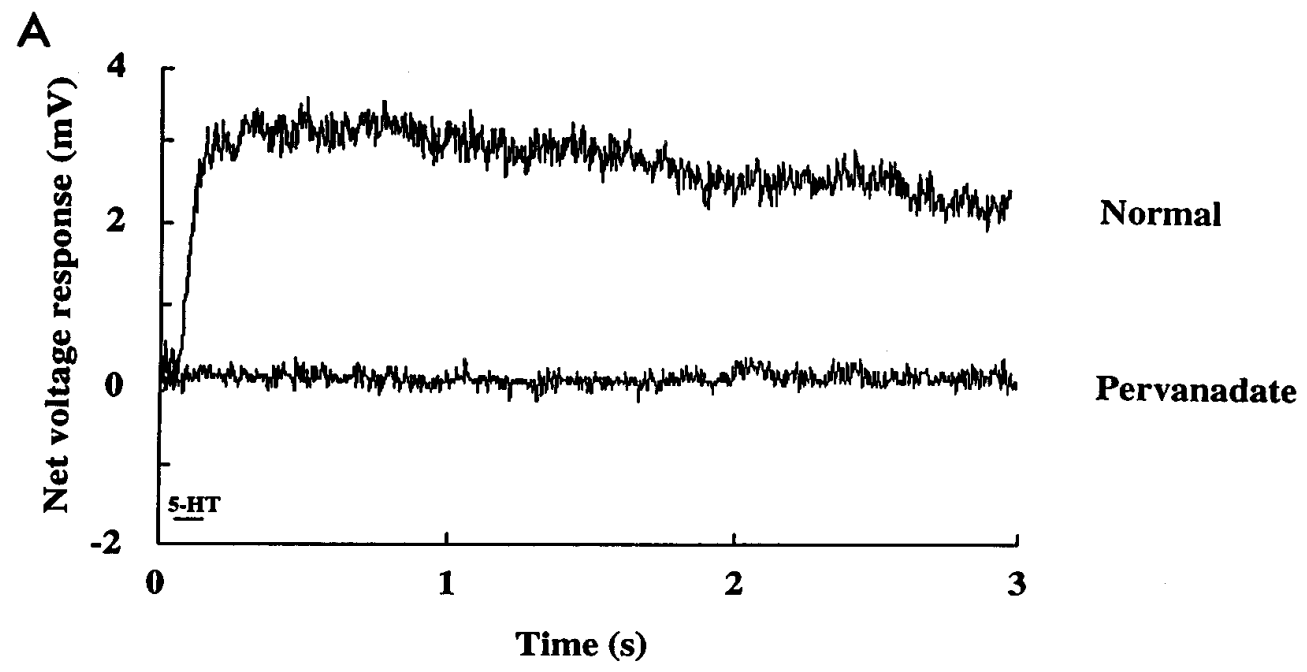

B

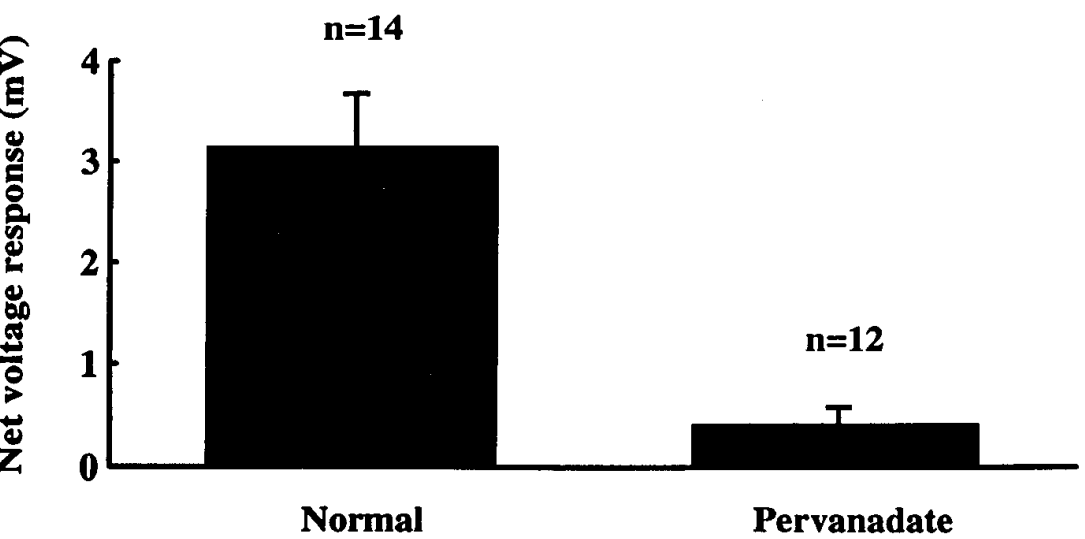

Figure 1. Effect of pervanadate on $\mathrm{P}$ cell depolarization by 5-HT. $A$, The net voltage response (relative to the resting potential of $-50 \mathrm{mV}$ ) to brief application of 5-HT was measured in cultured P cells using an intracellular electrode in either the absence (Nor$\mathrm{mal}$ ) or presence of pervanadate. $B$, Histogram summarizing the voltage responses recorded in control $\mathrm{P}$ cells and in $\mathrm{P}$ cells treated with pervanadate. The number of experiments $(n)$ is indicated for each group, and the error bars represent the SEM.

DMSO to yield a final concentration of 0.5 or $30 \mu \mathrm{M}$, respectively. This diluted DMSO concentration had no effect on the cellular properties. Recordings were filtered at $1 \mathrm{kHz}(-3 \mathrm{~dB})$, digitized at $10 \mathrm{kHz}$, and stored for later analysis using pClamp software (Axon Instruments, Foster City, CA).

Inside-out recordings were obtained as described previously (Catarsi and Drapeau, 1992, 1993) and differed from the procedure described above for cell-attached patches in that $1.5 \mathrm{~mm}$ EGTA was added to the solutions to reduce the free calcium concentration and facilitate patch excision. Rat brain PKC (Terochem Laboratories) was added at a final concentration of $1 \mathrm{pU} / \mu \mathrm{l}$ in the presence of $1 \mathrm{mM}$ ATP and $0.1 \mu \mathrm{M}$ PMA. Truncated CD45 T-cell protein tyrosine phosphatase (PTPase) was a gift from Dr. E. H. Fischer (University of Washington, Seattle, WA) and was added at a final concentration of $50 \mathrm{nM}$.

\section{RESULTS}

As a measure of its macroscopic effect, 5-HT (1 mM) was applied briefly (for $100 \mathrm{msec}$ ) onto $\mathrm{P}$ cells in culture while the membrane potential was recorded with an intracellular microelectrode. As shown in Figure $1 A, B$, this resulted in a prolonged depolarization (lasting several seconds) of the P cells (peak depolarization of 3.1 $\mathrm{mV} \pm 0.5 ; n=14)$. When the $\mathrm{P}$ cells were exposed to sodium pervanadate $(100 \mu \mathrm{M})$, a membrane-permeant form of vanadate, before testing the response to $5-\mathrm{HT}$, this resulted in a significant suppression of the depolarization $(0.4 \mathrm{mV} \pm 0.2 ; n=12 ; p<0.001$ by ANOVA) (Fig. $1 A, B)$. Pervanadate applied alone did not affect the physiological properties of the P cells (Aniksztejn et al., 1997).

Our previous work has shown that the depolarizing response to 5-HT is attributable to activation of cation channels by PKC, which increases the frequency of channel openings without af- fecting the mean open time or current amplitude (Drapeau, 1990; Catarsi and Drapeau, 1992). The channels are easily recognized during patch-clamp recordings because of their characteristic properties, which include spontaneous (frequency of $\sim 1 \mathrm{~Hz}$ ), brief (duration of $\sim 1 \mathrm{msec}$ ), and large channel openings (conductance of $60 \mathrm{pS})$ at the resting membrane potential $(-50 \mathrm{mV})$ in the absence of 5-HT. We therefore examined whether pervanadate could inhibit the activation of cation channels. In cellattached recordings, activation of endogenous PKC by PMA (0.5 $\mu \mathrm{M})$ increased channel activity (3.6 \pm 0.8 -fold increase; $n=14)$; the mean open time and current amplitude were unaffected (Fig. $2 A, C$ ), as reported previously (Drapeau, 1990; Catarsi and Drapeau, 1993). Because the patches had more than one channel, we could not determine accurately the close times, which were expected to be reduced to account for the increased rate of channel openings that we observed. When the P cells were exposed to pervanadate before application of PMA, the latter resulted in a small stimulation of channel activity $(1.6 \pm 0.3$-fold increase; $n=14$ ) (Fig. 2B,C). This effect was significantly lower than in the absence of pervanadate $(p=0.02)$, and the mean open time and current amplitude were unaffected. Application of pervanadate alone had no effect $(p=0.2)$ on channel activity $(1.2 \pm 0.2 ; n=7)$ (Fig. $2 C$ ).

To examine whether inhibition of tyrosine phosphatases could suppress PKC modulation of cation channels isolated from $\mathrm{P}$ cells, we excised membrane patches in the inside-out configuration. When patches were held at a potential of $50 \mathrm{mV}$ (i.e., -50 

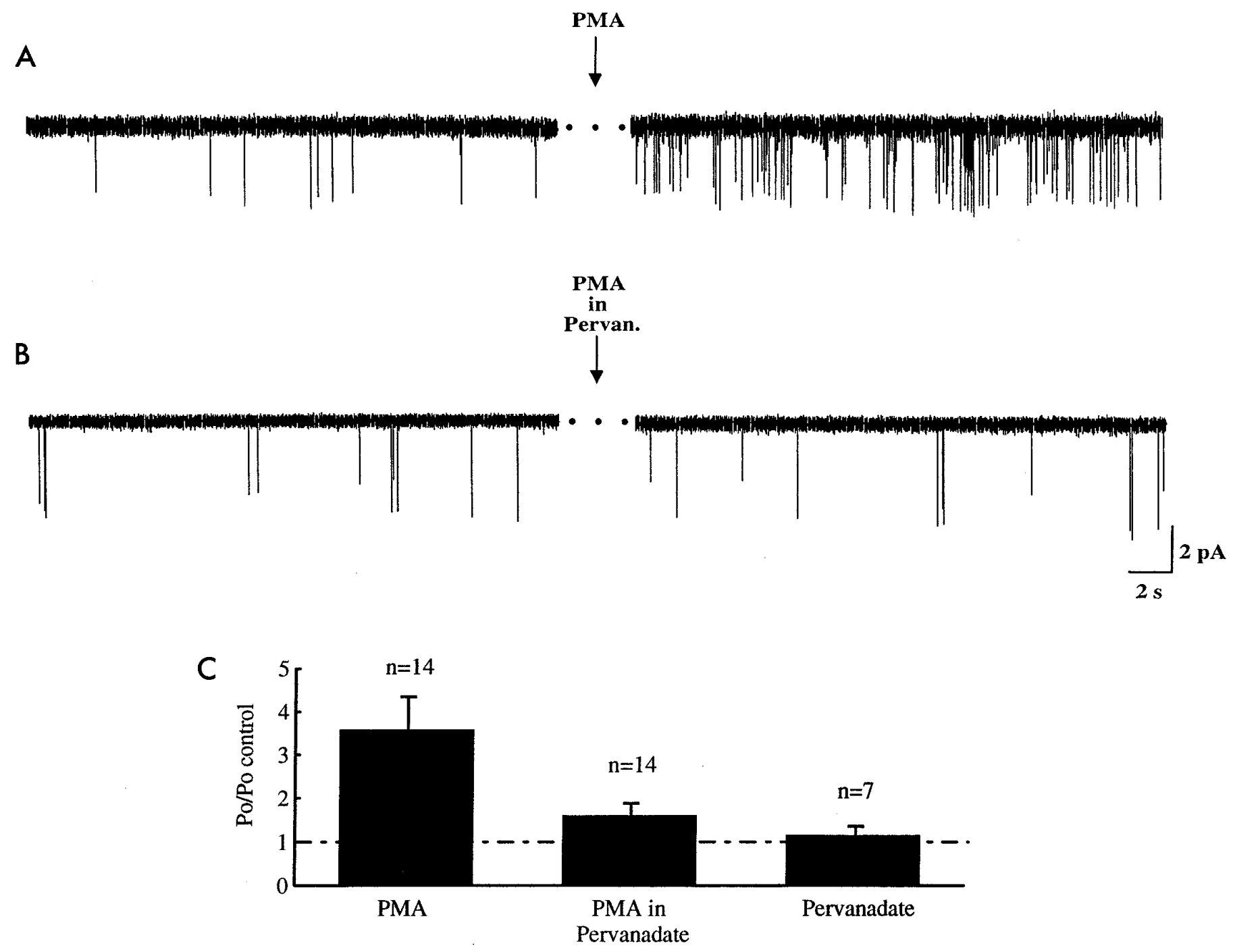

Figure 2. Effect of pervanadate on PMA activation of cation channels in cell-attached patches. $A$, Current traces $(20$ sec $)$ of cation channel activity at the resting potential in a cell-attached patch before (left $)$ and after (right) application of $0.5 \mu \mathrm{M}$ PMA (indicated by the arrow). Note that PMA increased the number of channel openings. The current amplitude, probability of channel opening $\left(P_{o}\right)$, and mean open times (MOTs) were $-2.1 \mathrm{pA}, 0.0006$ and $0.89 \mathrm{msec}$ before, and $-1.9 \mathrm{pA}, 0.0034$ and $0.89 \mathrm{msec}$ after addition of PMA. $B$, Current recordings $(20 \mathrm{sec})$ in the presence of $100 \mu \mathrm{M}$ pervanadate before (left) and after (right) the application of PMA. Note that in contrast to the traces depicted in $A$, PMA no longer increased channel activity. The values for the current amplitude, $P_{\mathrm{o}}$, and MOT were $-2.8 \mathrm{pA}, 0.0013$ and $0.75 \mathrm{msec}$ before, and $-2.8 \mathrm{pA}, 0.0009$ and $0.70 \mathrm{msec}$ after addition of PMA. $C$, Histogram summarizing the ratio of $P_{\mathrm{o}}$ after relative to before $\left(P_{o} / P_{o}\right.$ control) treatments with PMA (left), PMA in pervanadate (middle), and pervanadate alone (right). The dashed line indicates the basal activity level.

$\mathrm{mV}$ in the pipette) and PKC was added to the bathing solution, channel activity increased $(4.6 \pm 0.8$-fold increase; $n=10)$; the mean open time and current amplitude were unaffected (Fig. $3 A, C$ ), as reported previously (Catarsi and Drapeau, 1992). When the patches were exposed to orthovanadate before the addition of PKC (Fig. 3B,C), no increase in channel activity was observed $(1.1 \pm 0.3$-fold increase; $n=8)$; this result was significantly different from the one observed with PKC in the absence of orthovanadate $(p<0.001)$. Exposure of patches to orthovanadate alone $(0.9 \pm 0.3$-fold effect; $n=8)$ (Fig. $3 C$ ) or exposure to orthovanadate after pretreating P cells with PMA $(1.1 \pm 0.2 ; n=$ 5) (Fig. 4B,C) had no significant effect on channel activity.

We next examined whether PKC and tyrosine phosphatase activities had additive effects or acted sequentially, i.e., with PKC activating a tyrosine phosphatase. As shown previously (Aniksztejn et al., 1997), exposing inside-out patches to a recombinant, catalytically active fragment of the CD45 T-cell PTPase (Zander et al., 1991) resulted in a $10.3 \pm 3.6$-fold increase in channel activity. In contrast, inside-out patches excised from $\mathrm{P}$ cells treated with PMA were not activated further by the addition of PTPase (1.4 \pm 0.6 -fold effect; $n=5$ ) (Fig. $4 A, C)$. This effect was significantly lower than that obtained with PTPase alone $(p<$ 0.04 ), suggesting a lack of additive effects. As an alternative, we pretreated $\mathrm{P}$ cells with the tyrosine kinase inhibitor genistein (Akiyama et al., 1987), because this should result in a progressive dephosphorylation by endogenous tyrosine phosphatases, previously shown to increase channel activity (Aniksztejn et al., 1997). After treatment with genistein, PMA failed to increase channel activity (Fig. $4 C)(1.0 \pm 0.1$-fold effect; $n=4)$, a result significantly different from that obtained with PMA alone $(p<0.05)$ and consistent with a lack of additive effects. Taken together, these results suggest that PKC activates a tyrosine phosphatase 

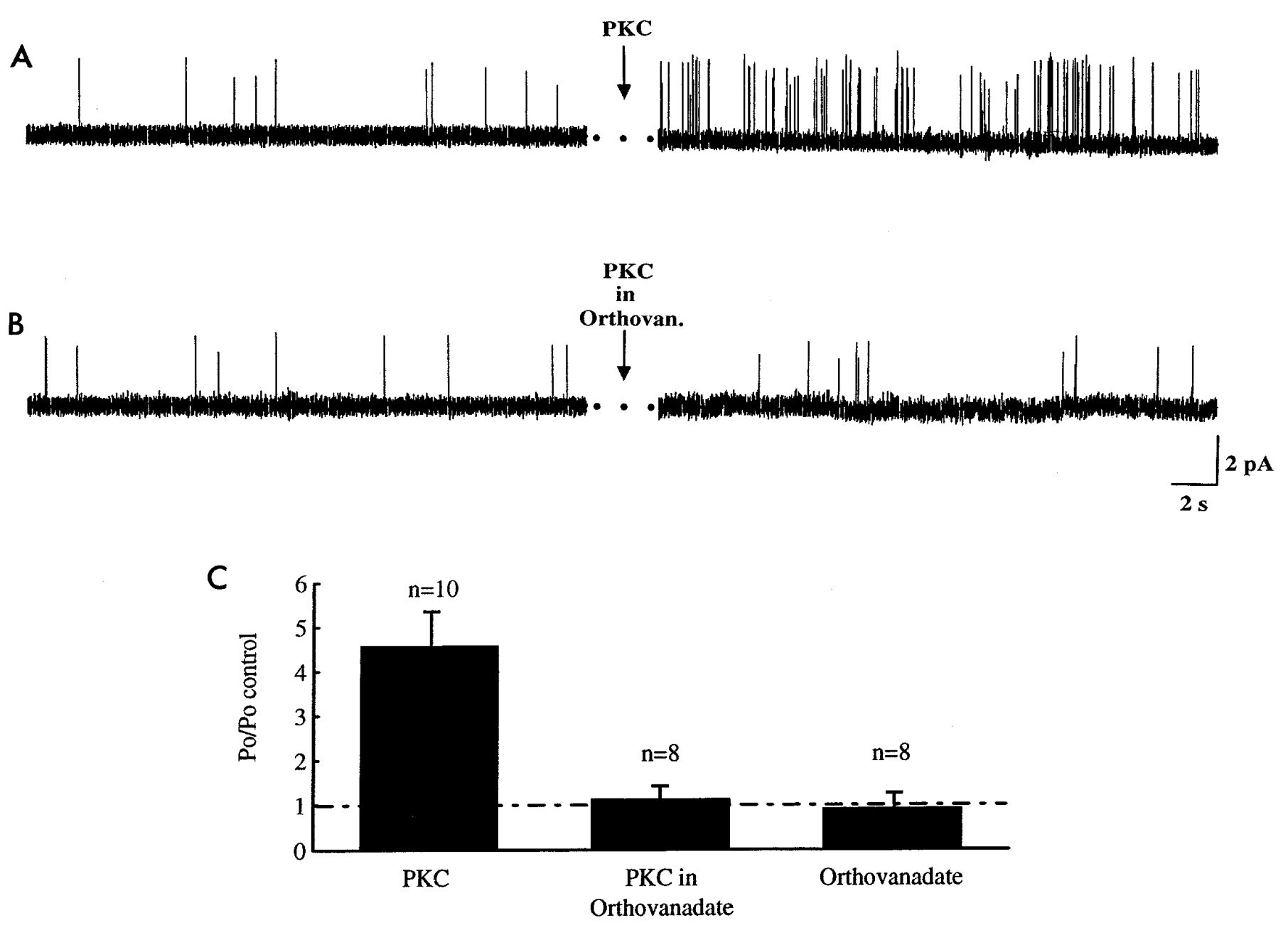

Figure 3. Effect of orthovanadate on PKC activation of cation channels in inside-out patches. $A$, Current traces (20 sec) of cation channel activity at $50 \mathrm{mV}$ (i.e., $-50 \mathrm{mV}$ in the pipette) in an inside-out patch before (left) and after (right) application of PKC (indicated by the arrow). Note that PKC increased the number of channel openings. The values for current amplitude, $P_{\mathrm{o}}$, and MOT were $2.2 \mathrm{pA}, 0.0025$ and $1.46 \mathrm{msec}$ before, and $1.9 \mathrm{pA}, 0.0126$ and $1.17 \mathrm{msec}$ after addition of PMA. B, Current recordings $(20 \mathrm{sec})$ in the presence of $100 \mu \mathrm{M}$ orthovanadate before (left) and after (right) the application of PMA. Note that in contrast to the traces depicted in $A$, PKC no longer increased channel activity. The values for current amplitude, $P_{\mathrm{o}}$, and MOT were $2.6 \mathrm{pA}, 0.0077$ and $1.71 \mathrm{msec}$ before, and $2.6 \mathrm{pA}, 0.0078$ and $1.71 \mathrm{msec}$ after addition of PMA. $C$, Histogram summarizing the ratio of $P_{\mathrm{o}}$ after relative to before $\left(P_{o} / P_{o}\right.$ control $)$ treatments with PKC (left), PKC in orthovanadate (middle), and orthovanadate alone (right).

activity sequentially, rather than having independent, additive effects on the channels.

\section{DISCUSSION}

Our results show that the stimulation of cation channels by 5 -HT, or by its intracellular mediator PKC, is blocked when tyrosine phosphatases are inhibited, suggesting that reversal of constitutive tyrosine phosphorylation increases the activity of these channels (Fig. 5). Because this is also true for channels in isolated membrane patches, the simplest interpretation is that a tyrosine phosphatase is closely associated with the channels in the patch and is activated by PKC, as has been shown for some tyrosine phosphatases (Zor et al., 1993; Kiyomoto et al., 1994). This conclusion is supported by the lack of evidence for additive effects of PKC and tyrosine phosphatase. An alternative possibility is that PKC may inhibit a tyrosine kinase, but this is unlikely because we have shown that inhibitors of tyrosine kinases have no effect on the responses to 5-HT (Ching et al., 1993) and PMA (Catarsi and Drapeau, 1993). No "run-up" of activity was observed with inside-out patches in the absence of ATP (Catarsi and Drapeau, 1992; Aniksztejn et al., 1997), indicating that the phosphatase activity is inactive at rest. Neuromodulation by 5-HT is thus likely attributable to PKC activation of an otherwise inactive tyrosine phosphatase that then dephosphorylates the cation channels with which it is intimately associated. Interestingly, the mode of gating of a cation channel in Aplysia bag cells is switched to a higher activity pattern by a tyrosine phosphatase that is regulated by a serine/threonine kinase within membrane patches, suggesting a close association between the phosphatase and the channel (Wilson and Kaczmarek, 1993). Our results suggest that the regulation of channel-associated tyrosine phosphatases may be a final step in the signaling cascades of serine/ threonine kinases during neuromodulation. In contrast to signaling by transient serine/threonine phosphorylation of target molecules, transient tyrosine dephosphorylation may signal neuromodulation.

Tyrosine phosphorylation is emerging as an important signal not only for early events during cellular differentiation (Cantley et al., 1991; Greenwald and Rubin, 1992) but also for neuronal 

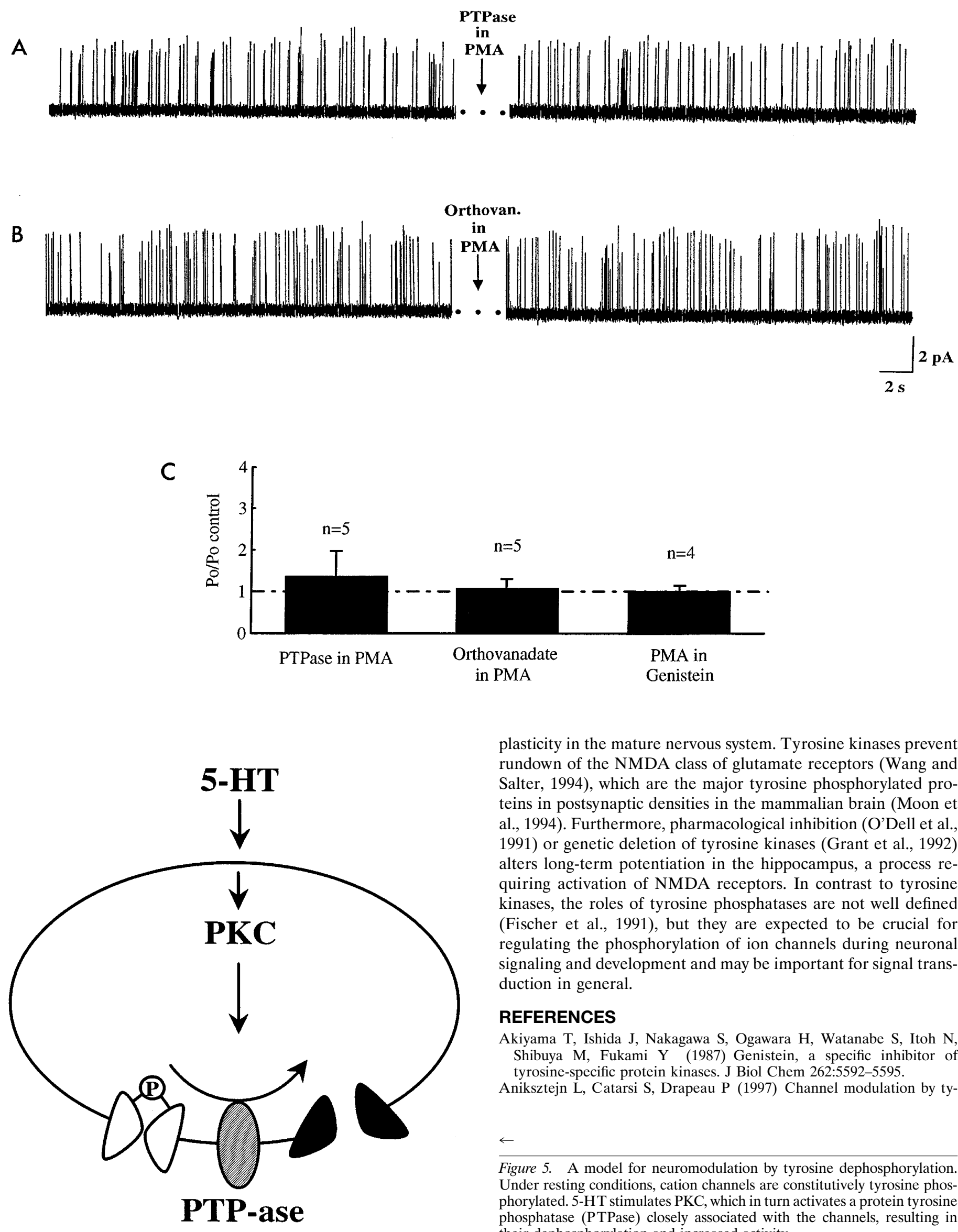

plasticity in the mature nervous system. Tyrosine kinases prevent rundown of the NMDA class of glutamate receptors (Wang and Salter, 1994), which are the major tyrosine phosphorylated proteins in postsynaptic densities in the mammalian brain (Moon et al., 1994). Furthermore, pharmacological inhibition (O'Dell et al., 1991) or genetic deletion of tyrosine kinases (Grant et al., 1992) alters long-term potentiation in the hippocampus, a process requiring activation of NMDA receptors. In contrast to tyrosine kinases, the roles of tyrosine phosphatases are not well defined (Fischer et al., 1991), but they are expected to be crucial for regulating the phosphorylation of ion channels during neuronal signaling and development and may be important for signal transduction in general.

\section{REFERENCES}

Akiyama T, Ishida J, Nakagawa S, Ogawara $\mathrm{H}$, Watanabe $\mathrm{S}$, Itoh $\mathrm{N}$, Shibuya M, Fukami Y (1987) Genistein, a specific inhibitor of tyrosine-specific protein kinases. J Biol Chem 262:5592-5595. Aniksztejn L, Catarsi S, Drapeau P (1997) Channel modulation by ty-

$\leftarrow$

Figure 5. A model for neuromodulation by tyrosine dephosphorylation. Under resting conditions, cation channels are constitutively tyrosine phosphorylated. 5-HT stimulates PKC, which in turn activates a protein tyrosine phosphatase (PTPase) closely associated with the channels, resulting in their dephosphorylation and increased activity. 
rosine phosphorylation in an identified leech neuron. J Physiol (Lond) 498:135-142.

Cantley LC, Auger KR, Carpenter C, Duckworth B, Graziani A, Kapeller R, Soltoff S (1991) Oncogenes and signal transduction. Cell 64:281-302.

Catarsi S, Drapeau P (1992) Loss of extrasynaptic channel modulation by protein kinase $\mathrm{C}$ underlies the selection of serotonin responses in an identified leech neuron. Neuron 8:275-281.

Catarsi S, Drapeau P (1993) Tyrosine kinase-dependent selection of transmitter responses induced by neural contact. Nature 363:353-355.

Catarsi S, Ching S, Merz DC, Drapeau P (1995) Tyrosine phosphorylation during synapse formation between identified leech neurons. J Physiol (Lond) 485:775-786.

Ching S, Catarsi S, Drapeau P (1993) Selection of transmitter responses at sites of neurite contact during synapse formation between identified leech neurons. J Physiol (Lond) 468:425-439.

Dietzel ID, Drapeau P, Nicholls JG (1986) Voltage dependence of 5-hydroxytryptamine release at a synapse between identified leech neurons in culture. J Physiol (Lond) 372:191-205.

Drapeau P (1990) Loss of channel modulation by transmitter and protein kinase $\mathrm{C}$ during innervation of an identified leech neuron. Neuron 4:875-882.

Fischer EH, Charbonneau H, Tonks NK (1991) Protein tyrosine phosphatases: a diverse family of intracellular and transmembrane enzymes. Science 253:401-406.

Grant SGN, O'Dell TJ, Karl KA, Stein PL, Soriano SP, Kandel ER (1992) Impaired long-term potentiation, spatial learning, and hippocampal development in fyn mutant mice. Nature 258:1903-1910.

Greenwald I, Rubin GM (1992) Making a difference: the role of cell-cell interactions in establishing separate identities for equivalent cells. Cell 68:271-281.

Holmes TC, Fadool DA, Levitan IB (1996a) Tyrosine phosphorylation of the Kv1.3 potassium channel. J Neurosci 16:1581-1590.

Holmes TC, Fadool DA, Ren R, Levitan IB (1996b) Association of Src tyrosine kinase with a human potassium channel mediated by $\mathrm{SH} 3$ domain. Science 274:2089-2091.

Hopfield JF, Tank DW, Greengard P, Huganir RL (1988) Functional modulation of the nicotinic acetylcholine receptor by tyrosine phosphorylation. Nature 336:677-680.

Huang X-Y, Morielli AD, Peralta EG (1993) Tyrosine kinasedependent suppression of a potassium channel by the $G$ proteincoupled m1 muscarinic acetylcholine receptor. Cell 75:1145-1156.

Jonas EA, Knox RJ, Kaczmarek LK, Schwartz JH, Solomon DH (1996) Insulin receptor in Aplysia neurons: characterization, molecular cloning, and modulation of ion currents. J Neurosci 16:1645-1658.

Kaczmarek LK, Levitan IB (1987) Neuromodulation: the biochemical control of neuronal excitability. New York: Oxford UP.

Kiyomoto H, Fouqueray B, Abboud HE, Choudhury GG (1994) Phorbol 12-myristate 13-acetic acid inhibits PTP1B activity in human mesangial cells: a possible mechanism of enhanced tyrosine phosphorylation. FEBS Lett 353:217-220.
Lev S, Moreno H, Martinez R, Canoll P, Peles E, Musacchio JM, Plowman GD, Rudy B, Schlessinger J (1995) Protein tyrosine kinase PYK2 involved in $\mathrm{Ca}^{2+}$-induced regulation of ion channel and MAP kinase functions. Nature 376:737-745.

Llinas R, Moreno H, Sugimori M, Mohammadi M, Schlessinger J (1997) Differential pre- and postsynaptic modulation of chemical transmission in the squid giant synapse by tyrosine phosphorylation. Proc Natl Acad Sci USA 94:1990-1994.

Mar A, Drapeau P (1996) Modulation of conduction block in leech mechanosensory neurons. J Neurosci 16:4335-4343.

Martin GR, Humphrey PPA (1994) Receptors for 5-hydroxytryptamine: current perspectives on classification and nomenclature. Neuropharmacology 33:261-273.

Moon IS, Apperson ML, Kennedy MB (1994) The major tyrosinephosphorylated protein in the postsynaptic density fraction is $N$-methylD-aspartate receptor subunit 2B. Proc Natl Acad Sci USA 91:3954-3958.

Moss SJ, Gorrie GH, Amato A, Smart TG (1995) Modulation of $\mathrm{GABA}_{\mathrm{A}}$ receptors by tyrosine phosphorylation. Nature 377:344-348.

O'Dell TJ, Kandel ER, Grant SGN (1991) Long-term potentiation in the hippocampus is blocked by tyrosine kinase inhibitors. Nature 353:558-560.

Peroutka SJ (1993) 5-hydroxytryptamine receptors. J Neurochem 60: 408-416.

Sanchez-Armass S, Merz DC, Drapeau P (1991) Distinct receptors, second messengers and conductances underlying the dual responses to serotonin in an identified leech neuron. J Exp Biol 155:531-547.

Swarup G, Cohen S, Garbers DL (1982) Inhibition of membrane phosphotyrosyl-protein phosphatase activity by vanadate. Biochem Biophys Res Commun 107:1104-1109.

Valenzuela CF, Machu TK, McKernan RM, Whiting P, VanRenterghem BB, McManaman JL, Brozowski SJ, Smith GB, Olsen RW, Harris RA (1995) Tyrosine kinase phosphorylation of $\mathrm{GABA}_{\mathrm{A}}$ receptors. Mol Brain Res 31:165-172.

Wallace BG (1995) Regulation of interaction of nicotinic acetylcholine receptors with the cytoskeleton by agrin-activated protein tyrosine kinase. J Cell Biol 128:1121-1129.

Wang YT, Salter MW (1994) Regulation of NMDA receptors by tyrosine kinases and phosphatases. Nature 369:233-235.

Wilson GF, Kaczmarek LK (1993) Mode-switching of a voltage-gated cation channel is mediated by a protein kinase A-regulated tyrosine phosphatase. Nature 366:433-438.

Zander NF, Lorenzen JA, Cool DE, Tonks NK, Daum G, Krebs EG, Fischer EH (1991) Purification and characterisation of a human recombinant T-cell protein-tyrosine-phosphatase from a bacculovirus expression system. Biochemistry 30:6964-6970.

Zor U, Ferber E, Gergely P, Szucs K, Dombradi V, Goldman R (1993) Reactive oxygen species mediate phorbol ester-regulated tyrosine phosphorylation and phospholipase A2 activation: potentiation by vanadate. Biochem J 295:879-888.

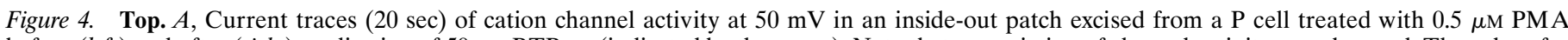

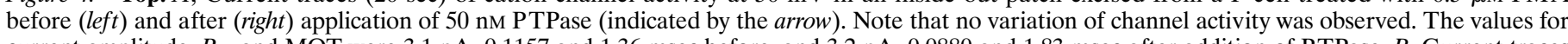

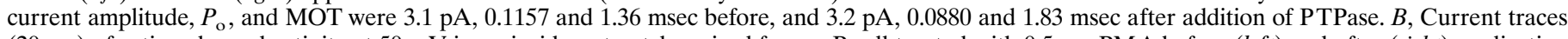

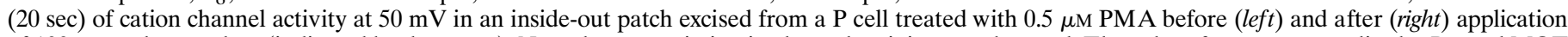

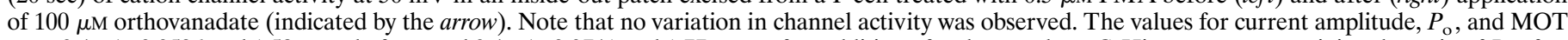

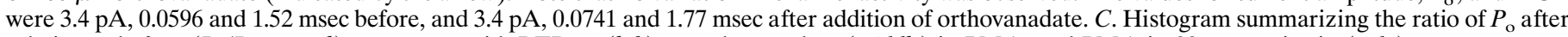
relative to before $\left(P_{o} / P_{o}\right.$ control) treatments with PTPase (left) or orthovanadate (middle) in PMA, and PMA in $30 \mu \mathrm{M}$ genistein (right). 